\title{
Analysis of propulsion units dedicated to test stands for aviation systems
}

This paper presents an analysis of selected propulsion units dedicated to test stands for unmanned aircraft systems. It focuses on engines suitable for aircraft with a maximum take-off mass up to $150 \mathrm{~kg}$. The study includes an analysis of propulsion units that can be used to power systems on stationary test stands dedicated to advanced research and measurement of prototype aerospace technologies intended for use in rotorcraft. The analysis of propulsion units shows that electric units are a better choice for powering UAV rotorcraft test stands. Their main advantages include the possibility to simplify the construction of the device by eliminating gears and to mount the motor in a vertical position, simpler power supply, cooling and control systems and the lack of an exhaust system. Additional advantages are undoubtedly lower vibration generation, cheaper and easier operation as well as better comfort.

Key words: combustion engine, electric motor, test stand, unmanned aerial vehicle

\section{Introduction}

Not so long ago, it seemed that the beginning of the $21^{\text {st }}$ century would be a period of intense aviation development. The transport of people and goods by air has increased its market share every year $[10,16]$. Environmental regulations are increasingly influencing the type of transport used [11], but the market for unmanned aerial vehicles is experiencing intensive development, both in terms of the technologies used and the scope of use of unmanned aerial systems $[5,8]$. Diverse technologies for enhancing the operational capabilities of UAVs are used and considered.

For propulsion of unmanned aerial vehicles weighing more than $50 \mathrm{~kg}$, propeller power units with two- or fourstroke piston engines are mainly used. It is characteristic that while in UAV with mass between $50 \mathrm{~kg}$ and $100 \mathrm{~kg}$ engines of various manufacturers are used, whereas in the mass range of $100-500 \mathrm{~kg}$ is dominated by rotary piston engines. Internal combustion engines are popularly used to power manned ultralight aircraft, by their high reliability, relatively long overhaul intervals (of the order of several hundred hours), which are at least several times lower than the prices of engines manufactured exclusively for unmanned aerial vehicles.

Regardless of the concept of conducted research, it is essential to test new systems before launching the aircraft onto the market. The first stage is computer-aided design and numerical fluid mechanics testing [15]. The next stage is bench testing [18]. The preparation of a bench and the selection of a suitable power unit determine the success and efficiency of research. The dynamic development of the engine market and the seemingly abundant offer and possibilities of applying selected power units to flying prototype systems make it possible to freely shape test stands. This publication focuses on the analysis of propulsion units that can be used to power systems on stationary test stands dedicated to advanced research and measurement of prototype aircraft technologies for rotorcraft. The paper points out that appropriately selected propulsion units have a decisive influence on the effects of conducted research. Based on commercially available engines and manufacturers' data, the main parameters for analysis are presented. The benefits of using specific solutions are indicated and the risks asso- ciated with the use of an inappropriate power unit are defined. Selection of a proper propulsion unit is an example of how to optimise energy consumption and emissions of target flying systems.

This study focuses on the analysis of aircraft with an MTOM of $150 \mathrm{~kg}$, equipped with different propulsion systems. Part of research focuses on the use of alternative fuels in already existing internal combustion engines, e.g. synthetic fuels in a Wankel engine [17] or the modification of engine assistance systems to reduce emissions [6]. The use of a compression ignition engine in light aviation is also being considered and such aircraft are already in service [19]. Research is also underway to develop an aviation diesel engine with opposed pistons [7, 20]. Other concepts to reduce emissions or aircraft power demand are related to interference with aircraft aerodynamics [2] or the use of modern construction materials [22] or even interference with an aircraft shape through the use of smart materials [1, 3].

Thus, it is one thing to select an internal combustion engine for an aircraft and another to select an engine to drive a propeller system test stand. In particular, the following aspects are important: absence of reduction gearbox, ability to operation in any position, vibration, weight and size. These and other aspects will be analyzed in this paper.

\section{Materials and methods}

The methodology used in this study enables us analyse and evaluate literature resources. In addition, solutions offered on the market are reviewed and their suitability for the test bench is determined.

\subsection{Selection of basic engine parameters}

Unmanned helicopters with a take-off weight of up to $150 \mathrm{~kg}$ are powered by internal combustion or electric engines. An analysis of existing designs has shown that the minimum power demand and engine torque depend on the rotor design, size and operating parameters. According to the calculations carried out, for a $2 \mathrm{~m}$ diameter main rotor design with a maximum speed of $1500 \mathrm{rpm}$, the parameters of the required power and torque are $25 \mathrm{~kW}$ and $150 \mathrm{Nm}$, respectively. An exemplary aircraft with the given take-off mass is the UMS SKELDAR R-350 (Fig. 1) powered by a $25 \mathrm{~kW}$ turboshaft engine [26]. 


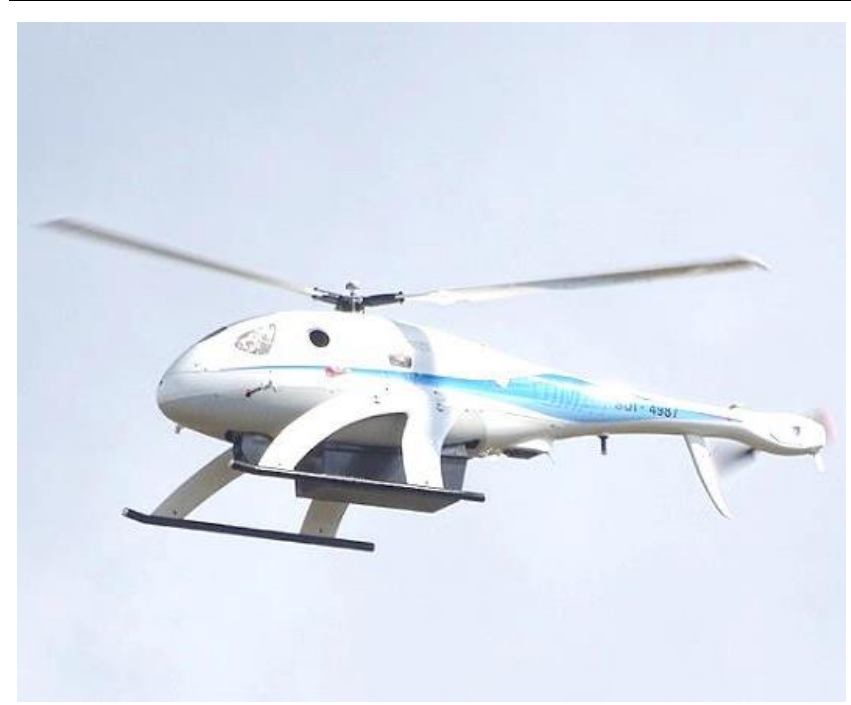

Fig. 1. UMS SKELDAR R-350 unmanned helicopter [25]

\subsection{Combustion engines}

Two aircraft combustion power units were analysed. The first is a two cylinder two-stroke inline engine - the F23 Lightweight (Fig. 2) manufactured by Hirth Engines. It is used to power, among others, the Solid Air Diamant LP (ultralight trike) and the Aeronix Airelle (ultralight tandem wing). The second engine is the AR731 from UAV ENGINES. This is a Wankel engine specifically manufactured for use in UAVs.

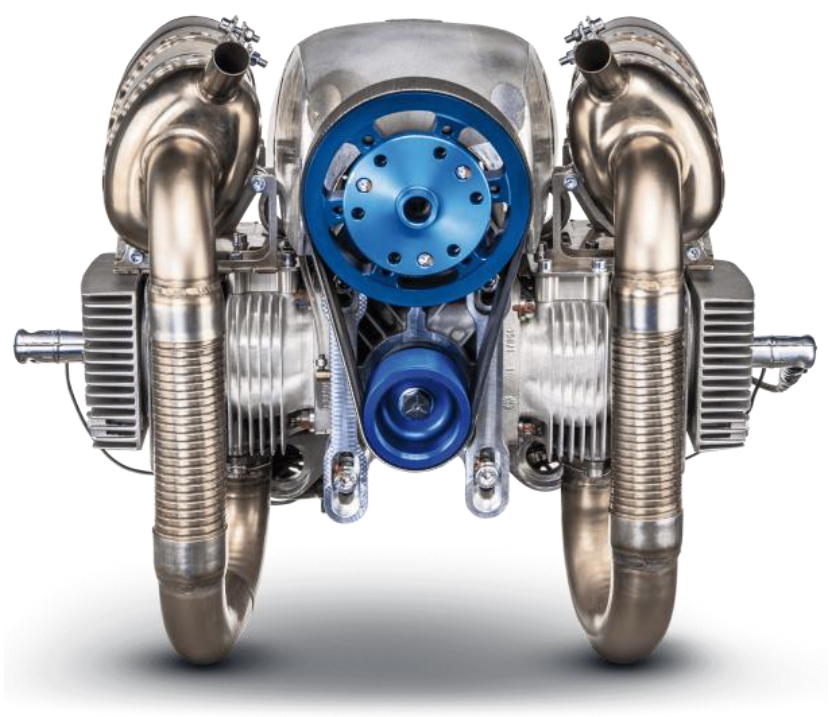

Fig. 2. View of the F23 Lightweight engine [21]

\subsection{Electric motors}

Electric motors were also analysed here due to their increasing use in aircraft propulsion and the conditions of use of the test stand. Three types of units were considered here, i.e. an induction motor, a permanent magnet synchronous motor (PMSM), and a brushless direct current motor (BLDC).

The first of these is the industrial solution of TAMEL 4Sg200L-4-IE2 (Fig. 3). It is an induction motor with improved efficiency, the IE2 class according to IEC6003430:2009.

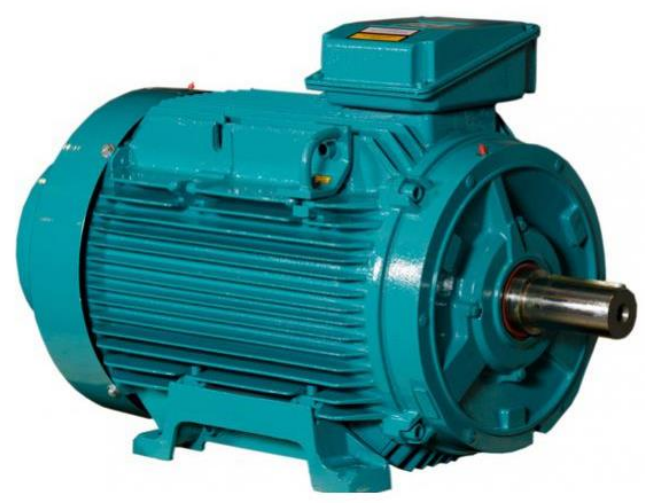

Fig. 3. View of the 4Sg200L-4-IE2 motor [23]

The other proposed units are permanent magnet motors. The PMSM type motor analysed was a product from VEM with the symbol PE1R200L4, also manufactured for industrial applications.

The last drive unit included in the review was REB 30 from the Czech company MGM COMPRO, representing BLDC type motors. Its parameters are only close to those required. This is due to the low availability of engines of this type on the market which meet the required assumptions. Such motors are not very popular and the full specification of these units is not available. The presented engine is a product used mainly in aviation, for propelling VTOL aircraft and drones. The specific design of the engine is shown in Fig. 4.

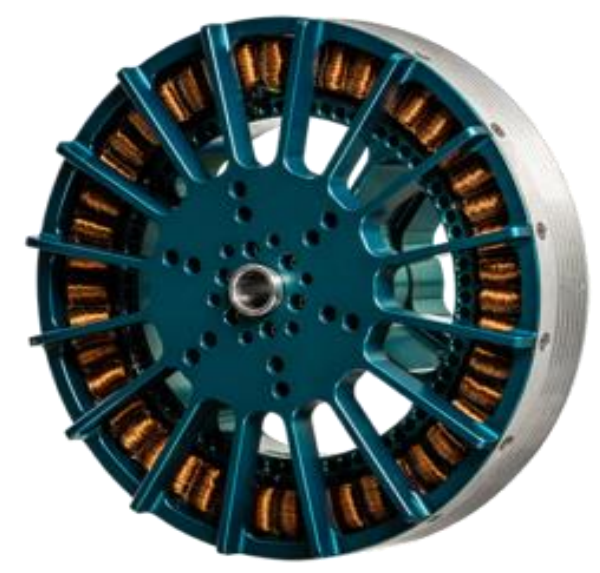

Fig. 4. REB30 motor [12]

\section{Results}

\subsection{Combustion engines}

Selected internal combustion engine parameters collected during the analysis of existing designs are given in Table 1.

Both of these drive units meet the power requirements of a test rig for rotorcraft with a take-off mass of up to 150 $\mathrm{kg}$. However, it is very important to note that for both engines, mechanical transmissions are required to achieve the desired torque and speed. This complicates the construction of the test stand and, consequently, affects the economic aspect, increasing the cost of the device. This is undoubted- 
ly a disadvantage of the use of internal combustion engines, as their operating range covers rotational speeds significantly exceeding the values required on the rotorcraft test stand. The AR731 engine reaches its highest torque at about 7000 rpm and maximum power at $8000 \mathrm{rpm}$ and the F23 at 6500 rpm respectively (Fig. 5).

Table 1. Selected parameters of internal combustion engines [14, 24]

\begin{tabular}{|l|c|c|c|}
\hline Parameter & Unit & F23 Lightweight & AR731 \\
\hline Engine type & - & Boxer & Wankel \\
\hline Maximum power & $\mathrm{kW}$ & $36.7(6500 \mathrm{rpm})$ & $28.3(8000 \mathrm{rpm})$ \\
\hline Maximum torque & $\mathrm{Nm}$ & $53.0(6300 \mathrm{rpm})$ & $35.5(7000 \mathrm{rpm})$ \\
\hline $\begin{array}{l}\text { Calculated torque } \\
\text { at } 1500 \mathrm{rpm}) \\
\text { a gearbox applied }\end{array}$ & $\mathrm{Nm}$ & 231 & 178 \\
\hline Weight & $\mathrm{kg}$ & 22 & 9.9 \\
\hline $\begin{array}{l}\text { Power-to-weight } \\
\text { ratio }\end{array}$ & $\mathrm{kW} / \mathrm{kg}$ & 1.67 & 2.86 \\
\hline Fuel & - & $\begin{array}{c}\text { Min. } 95 \text { octan fuel } \\
\text { with 2-stroke-oil }\end{array}$ & $\begin{array}{c}\text { Mogas regular } \\
\text { grade or Avgas } \\
100 \mathrm{LL}\end{array}$ \\
\hline Cooling & - & Air & Air \\
\hline Size & $\mathrm{mm}$ & $591 \times 493.5 \times 366$ & $328 \times 600 \times 262$ \\
\hline
\end{tabular}

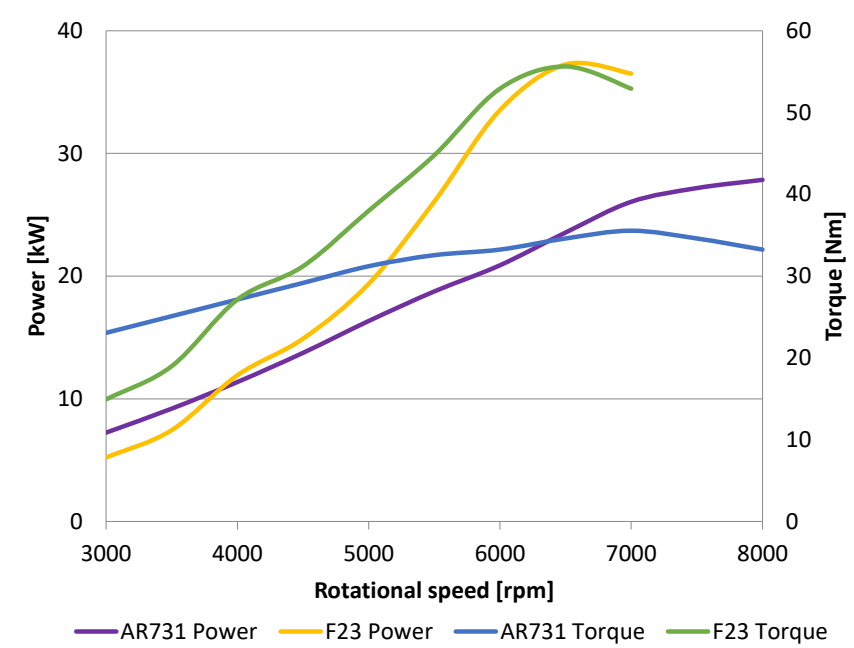

Fig. 5. External characteristics of AR731 and F23 engines [14, 24]

Another disadvantage of using internal combustion units is the need to purchase, store and supply fuel to the engine, and in the case of two-stroke engines, also to prepare a pileoil mixture such as the F23 Lightweight. This necessitates the construction of an adequate supply system in the laboratory, equipped with apparatus enabling the control and maintenance of fluid parameters such as temperature and pressure. In addition, the use of internal combustion engines requires the use of a fume extraction system for indoor testing. The disadvantages of such a solution also include the need for a special system enabling air cooling of drive units and a complicated system for controlling operating parameters and steering the drive unit.

An undoubted advantage of using a Wankel engine such as the AR731 is the low vibration level declared by the manufacturer [24]. In the case of combustion units with a different layout, there is a need to dampen generated vibrations.

\subsection{Electric motors}

Considering many disadvantages resulting from the use of internal combustion engines in test stands, electric en- gines were analysed. They offer a greater choice because of a wider market of units characterised by parameters similar to those required. Selected parameters of the engines under consideration are listed in Table 2.

Table 2. Parameters of selected electric motors [12, 23, 27]

\begin{tabular}{|c|c|c|c|c|}
\hline Parameter & Unit & $\begin{array}{c}4 \mathrm{Sg} 200 \mathrm{~L} \\
-4-\mathrm{IE} 2\end{array}$ & PE1R200L4 & REB 30 \\
\hline Motor type & - & Induction & PMSM & BLDC \\
\hline $\begin{array}{l}\text { Nominal } \\
\text { power }\end{array}$ & $\mathrm{kW}$ & $\begin{array}{c}30(1400 \\
\text { rpm })\end{array}$ & $\begin{array}{c}30(1500 \\
\mathrm{rpm})\end{array}$ & $25-30$ \\
\hline $\begin{array}{l}\text { Indicated } \\
\text { torque }\end{array}$ & $\mathrm{Nm}$ & 195 & 191 & 150 \\
\hline $\begin{array}{l}\text { Calculated } \\
\text { torque (at } \\
1500 \mathrm{rpm} \text { ) }\end{array}$ & $\mathrm{Nm}$ & 191 & 191 & N/A \\
\hline Weight & $\mathrm{kg}$ & 270 & 220 & 7.7 \\
\hline $\begin{array}{l}\text { Power-to- } \\
\text { weight } \\
\text { ratio }\end{array}$ & $\mathrm{kW} / \mathrm{kg}$ & 0.11 & 0.14 & 3.90 \\
\hline Supply & $\mathrm{V}$ & $400 \mathrm{AC}$ & $400 \mathrm{AC}$ & 63-800 DC \\
\hline Cooling & - & $\begin{array}{c}\text { Fan } \\
\text { integrated }\end{array}$ & $\begin{array}{c}\text { Fan } \\
\text { integrated }\end{array}$ & Air/hybrid \\
\hline Size & $\mathrm{mm}$ & $\begin{array}{c}400 \times 787 \\
\times 501\end{array}$ & $\begin{array}{c}400 \times 680 \\
\times 461\end{array}$ & $\begin{array}{c}267 \times 101 \\
\times 267\end{array}$ \\
\hline
\end{tabular}

The great advantage of electric motors is the existence of units with sufficient power and speeds close to the required one and still generating sufficient torque. Speed control can be performed with an inverter, which is a much simpler method than in the case of internal combustion engines. This allows the relevant parameters (speed and torque) to be achieved without the need for reduction gears. Additionally, they can be used in any position, which allows them to be placed vertically under the rotor and the shafts to be axially aligned without additional bevel gears. An electrical system is required to power the motors, which is generally a simpler solution than a fuel supply system. In the case of DC motors, additional AC-DC converters are required, which somewhat complicates the installation. An alternative is battery power. However, this is less advantageous due to the cost of batteries and the need to recharge them. It must be ensured however that the electrical installation is of sufficient voltage to meet the power requirements of the engine. Moreover, most electric motors do not need additional cooling systems. The BLDC motor presented here is an exception, because it is used in aviation and there is a pursuit to reduce weight, taking into account the possibility of cooling while the aircraft is in motion. The advantage of electric motors is that they generate less vibration than internal combustion ones. A huge advantage is also their simpler and cheaper operation. They do not require periodic servicing, replacement of fluids and consumable parts. They are also less prone to faults due to their less complex construction. They also show higher efficiency, which reduces both operating costs and environmental pollution. The comfort of using electric motors is also higher, as their operation is quieter and their maintenance is cleaner [9]. A significant disadvantage of using electric motors is cables with relatively high voltage. They may adversely affect the indications of measuring devices. A good separation of signal wires and the use of shielding is a necessity. 
Induction motors and PMSMs are the largest in size and weight, while the presented BLDC motor is lighter and smaller than both these designs and internal combustion engines. The BLDC motor also has the highest power-toweight ratio. When used in an aircraft, these parameters would probably eliminate induction motors and PMSMs, but in the case of the test bench this is not a critical parameter. Larger size is not such a key issue, and significantly higher mass can even be an advantage as it adds weight to the bench. A significant disadvantage of BLDC motors is still the small number of products offered with a power of more than $20 \mathrm{~kW}$. In addition, most of the products on offer are only available to order, which increases waiting times and purchase costs. Due to their construction, BLDC motors and PMSMs have a larger speed control range than induction motors while maintaining high efficiency. In addition, they can be significantly overloaded. Higher efficiency of permanent magnet motors translates into smaller size and weight while maintaining similar electromechanical parameters [4].

Electric units generate high torque from the first motor revolutions [13]. Additionally, induction motors generate an even higher starting torque. This makes it easy to set the rotor in motion and removes the need to warm up the motor before testing, which would be the case for internal combustion engines. The induction type motor is also the most popular of electric motors, resulting in the widest choice, easy availability and lowest prices of the solutions considered.

\subsection{Comparison of internal combustion and electric motors}

Internal combustion engines and electric motors were compared Table 3 in terms of their advantages and disadvantages.

The advantages presented indicate the superiority of electric motors in application to UAV test stands.

\section{Conclusions}

The analysis of the motors shows that electric units are a better choice for powering UAV rotorcraft test stands. Their main advantages include the possibility to simplify the construction of the device by eliminating gears and to mount the motor in a vertical position, simpler power supply, cooling and control systems and the lack of an exhaust system. Additional advantages are undoubtedly lower vibration generation, cheaper and easier operation as well as better comfort.

Due to the fact that the offer of BLDC motors meeting the power requirements is limited, and the weight and size of the motor during ground tests do not play a key role, induction motors and PMSMs seem to be a better choice. These units are manufactured in many configurations, which allows for a favourable selection of performance parameters to meet demand. When choosing between a PMSM and an induction motor, it is worth remembering about the possibility of more accurate speed control while maintaining high efficiency in the case of a PMSM. Additionally, with similar parameters of operation it should be lighter and smaller than an induction motor. Additionally, an induction motor shows a high starting torque, which helps set the rotor in motion, while a PMSM requires appropriate control.

Table 3. Advantages and disadvantages of selected engines

\begin{tabular}{|c|c|c|}
\hline Aspect & Combustion engines & Electric motor \\
\hline Reduction gearbox & Necessary & Unnecessary \\
\hline Bevel gearbox & Necessary & Unnecessary \\
\hline $\begin{array}{l}\text { Operation in any } \\
\text { position }\end{array}$ & No & Yes \\
\hline Supply system & $\begin{array}{l}\text { Sophisticated, extra } \\
\text { measurement neces- } \\
\text { sary }\end{array}$ & $\begin{array}{l}\text { Electric installation } \\
\text { necessary, system } \\
\text { design simpler that in } \\
\text { combustion engines }\end{array}$ \\
\hline Exhaust gas system & Yes & No \\
\hline Control system & Sophisticated & Simple \\
\hline Cooling system & Necessary & Mostly unnecessary \\
\hline Vibration & Mostly high vibration & Low vibration \\
\hline $\begin{array}{l}\text { Measurement and } \\
\text { signal disturbance }\end{array}$ & None or low & $\begin{array}{l}\text { Possible due to high } \\
\text { voltage cables }\end{array}$ \\
\hline Weight & Low & $\begin{array}{l}\text { Higher, except for } \\
\text { BLDC motors }\end{array}$ \\
\hline Size & Smaller & $\begin{array}{l}\text { Larger, except for } \\
\text { BLDC motors }\end{array}$ \\
\hline Market availability & $\begin{array}{l}\text { Single limited series } \\
\text { on demand, no ideal } \\
\text { operations parame- } \\
\text { ters }\end{array}$ & $\begin{array}{l}\text { Single limited series of } \\
\text { BLDC motors, wide } \\
\text { offer, serial production } \\
\text { of PMSMs and induc- } \\
\text { tion motors }\end{array}$ \\
\hline Price & High & $\begin{array}{c}\text { BLDC/PMSM } \\
- \text { moderate } \\
\text { Induction }- \text { low } \\
\end{array}$ \\
\hline Maintenance costs & High & Low \\
\hline $\begin{array}{l}\text { Difficulty of opera- } \\
\text { tion }\end{array}$ & Higher & Lower \\
\hline Operation comfort & Lower & Higher \\
\hline
\end{tabular}

It should be remembered however that the final choice of a motor should be guided by the power and torque requirements for the case. In addition, the decision may be influenced by infrastructure and installations already in place, which is an individual matter for users.

\section{Acknowledgements}

This work has been financed by the National Centre for Research and Development under the LIDER program. Grant Agreement No. LIDER/45/0177/L-9/17/NCBR/2018.

\section{Nomenclature}

PMSM Permanent Magnet Synchronous Motor

BLDC Brushless Direct-Current Motor

VTOL Vertical Take Off and Landing

UAV Unmanned Aerial Vehicle

\section{Bibliography}

[1] AMEDURI, S., CONCILIO, A. Morphing wings review: aims, challenges, and current open issues of a technology. Proceedings of the Institution of Mechanical Engineers,
Part C: Journal of Mechanical Engineering Science. 2020. https://doi.org/10.1177/0954406220944423 
[2] BAI, C.-J., WANG, W.-C. Review of computational and experimental approaches to analysis of aerodynamic performance in horizontal-axis wind turbines (HAWTs). Renewable and Sustainable Energy Reviews. 2016, 63, 506-519. https://doi.org/https://doi.org/10.1016/j.rser.2016.05.078

[3] BARBARINO, S., BILGEN, O., AJAJ, R.M. et al. A review of morphing aircraft. Journal of Intelligent Material Systems and Structures. 2011, 22(9), 823-877.

https://doi.org/10.1177/1045389X11414084

[4] BERNATT, J., GAWRON, S., KRÓL, E. Nowoczesne silniki z magnesami trwałymi do zastosowań trakcyjnych. TTS Technika Transportu Szynowego. 2010, 16(1-2), 73-76.

[5] COLOMINA, I., MOLINA, P. Unmanned aerial systems for photogrammetry and remote sensing: a review. ISPRS Journal of Photogrammetry and Remote Sensing. 2014, 92, 7997. https://doi.org/10.1016/j.isprsjprs.2014.02.013

[6] FADHLI, M.H.W., DALI, A.L.A., MARKUS, S. et al. Optimization of charge motions for improving emissions internal combustion 4 stroke ROTAX engines. SAE Technical Paper 2007-24-0057. 2007. https://doi.org/10.4271/200724-0057

[7] GRABOWSKI, Ł., PIETRYKOWSKI, K., KARPIŃSKI, P. Charging process analysis of an opposed-piston two-stroke aircraft Diesel engine. ITM Web of Conferences. 2017, 15, 03002. https://doi.org/10.1051/itmconf/20171503002

[8] HASSANALIAN, M., ABDELKEFI, A. Classifications, applications, and design challenges of drones: a review. Progress in Aerospace Sciences. 2017, 91, 91-131. https://doi.org/10.1016/j.paerosci.2017.04.003

[9] KRÓL, E. Silniki synchroniczne w napędach pojazdów sportowo-rekreacyjnych. Zeszyty Problemowe - Maszyny Elektryczne. 2014, 102(2), 23-27.

[10] LIU, Y., KREIMEIER, M., STUMPF, E. et al. Overview of recent endeavors on personal aerial vehicles: a focus on the US and Europe led research activities. Progress in Aerospace Sciences. 2017, 91, 53-66. https://doi.org/10.1016/j.paerosci.2017.03.001

[11] MAYOR, K., TOL, R.S.J. Scenarios of carbon dioxide emissions from aviation. Global Environmental Change. 2010, 20(1), 65-73. https://doi.org/10.1016/j.gloenvcha.2009.08.001

[12] MGM COMPRO. MGM COMPRO 15-30 kW Electric Motors. 2021. https://www.mgm-compro.com/products/15 $30 \mathrm{kw}$-electric-motors/

[13] NEMŚ, A. Niskoemisyjne silniki: elektryczne czy spalinowe? Elektryczne, ale nasz system by tego nie wytrzymał Energia Gigawat, 2012, 8.

Ksenia Siadkowska, MEng. - Faculty of Mechanical Engineering, Lublin University of Technology, Poland.

e-mail: k.siadkowska@wp.pl

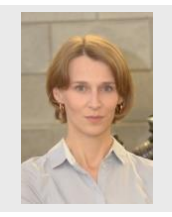

Karol Ścisłowski, MEng. - Faculty of Mechanical Engineering, Lublin University of Technology, Poland.

e-mail: k.scislowski@pollub.pl
[14] NORTHWEST UAV. F23 Lighweight 23 Series. 2021. www.nwuav.com

[15] SARAF, A.K., SINGH, M.P., CHOUHAN, T.S. Aerodynamic analysis of NACA0012 airfoil using CFD. International Journal of Mechanical and Production Engineering. 2017, 5(12), 21-25.

[16] SEHRA, A.K., WHITLOW, W. Propulsion and power for 21st century aviation. Progress in Aerospace Sciences. 2004, 40(4-5), 199-235.

https://doi.org/10.1016/j.paerosci.2004.06.003

[17] SIADKOWSKA, K., WENDEKER, M., MAJCZAK, A. et al. The influence of some synthetic fuels on the performance and emissions in a Wankel engine. SAE Technical Papers 2014-01-2611. 2014. https://doi.org/10.4271/2014-01-2611

[18] SIADKOWSKA, K. Wind tunnel research on the unmanned aerial vehicle rotor blade setting angle. Advances in Science and Technology Research Journal. 2020, 14(4), 104-114. https://doi.org/10.12913/22998624/126047

[19] SIADKOWSKA, K., MAJCZAK, A., BARAŃSKI, G. Studying a construction of pistons for the aircraft CI engine. Combustion Engines. 2017, 168(1), 161-167. https://doi.org/10.19206/CE-2017-126

[20] SOCHACZEWSKI, R., SZLACHETKA, M. Numerical analysis of a fuel pump for an aircraft Diesel engine. MATEC Web of Conferences. 2019, 252, 01003. https://doi.org/10.1051/matecconf/201925201003

[21] SUAS NEWS - BUSINESS OF DRONES. Northwest UAV, Hirth Engines sign distribution agreement for North and Central America. 2021.

https://www.suasnews.com/2020/09/northwest-uav-hirthengines-sign-distribution-agreement-for-north-and-centralamerica/

[22] SUROWSKA, B. Functional and hybrid materials in air transport. Eksploatacja i Niezawodność - Maintenance and Reliability 2008, 3, 30-40. http://www.ein.org.pl/sites/default/files/2008-03-04.pdf

[23] TAMEL S.A. Silniki IE2 w obudowie żeliwnej - 4Sg. 2009.

[24] UAV ENGINES. AR731- 38 BHP AV target engine. 2021.

[25] UMS SKELDAR SWEDEN AB. R-350 VTOL Remotely Piloted Aerial System. 2016.

[26] UMS SKELDAR SWEDEN AB. UMS SKELDAR R-350. 2021. https://umsskeldar.aero/our-products/land-solutions/

[27] VEM MOTORS GmbH. Permanent magnet synchronous motors for inverter operation. 2021.

Błażej Czajka, MEng. - Faculty of Mechanical Engineering, Lublin University of Technology, Poland.

e-mail: blazej.czajka@pollub.edu.pl

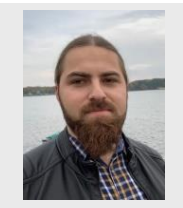

Prof. Mirosław Wendeker, DSc., DEng. - Faculty of Mechanical Engineering, Lublin University of Technology, Poland.

e-mail:m.wendeker@pollub.pl 